NBER WORKING PAPER SERIES

\title{
TOWARD ABSTRACTION: RANKING EUROPEAN PAINTERS OF THE EARLY TWENTIETH CENTURY
}

\author{
David W. Galenson \\ Working Paper 11501 \\ http://www.nber.org/papers/w11501 \\ NATIONAL BUREAU OF ECONOMIC RESEARCH \\ 1050 Massachusetts Avenue \\ Cambridge, MA 02138 \\ June 2005
}

The views expressed herein are those of the author(s) and do not necessarily reflect the views of the National Bureau of Economic Research.

(C2005 by David W. Galenson. All rights reserved. Short sections of text, not to exceed two paragraphs, may be quoted without explicit permission provided that full credit, including $\odot$ notice, is given to the source. 
Toward Abstraction: Ranking European Painters of the Early Twentieth Century David W. Galenson

NBER Working Paper No. 11501

July 2005

JEL No. J0

\begin{abstract}
$\underline{\text { ABSTRACT }}$
Paris was the undisputed capital of modern art in the nineteenth century, but during the early twentieth century major innovations began to occur elsewhere in Europe. This paper examines the careers of the artists who led such movements as Italian Futurism, German Expressionism, Holland's De Stijl, and Russia's Suprematism. Quantitative analysis reveals the conceptual basis of the art of Umberto Boccioni, Giorgio de Chirico, Kazimir Malevich, and Edvard Munch, and the experimental basis of the innovations of Wassily Kandinsky, Paul Klee, and Piet Mondrian. That the invention of abstract art was made nearly simultaneously by the conceptual Malevich and the experimental Kandinsky and Mondrian emphasizes the importance of both deductive and inductive approaches in the history of modern art.
\end{abstract}

\author{
David Galenson \\ Department of Economics \\ University of Chicago \\ 1126 East 59th Street \\ Chicago, IL 60637 \\ and NBER \\ galenson@uchicago.edu
}


In 1913 the poet Guillaume Apollinaire, who was perhaps the most sophisticated critic of the advanced art of his time, looked back on the history of modern painting and observed that "France in the nineteenth century produced the most varied and most innovative artistic movements." The reason was clear: "in the nineteenth century Paris was the capital of art." Apollinaire recognized, however, that "this movement was not exclusively French, but European. Englishmen like Constable and Turner, a German like Marées, a Dutchman like Van Gogh, and a Spaniard like Picasso have all played major roles in this movement." And by the time that Apollinaire wrote these words, he was aware that important new developments in modern art were occurring outside Paris: "This creative tendency is now spreading throughout the universe." Thus for example just in the course of 1913 Apollinaire would write in praise of the Italian painters Boccioni and de Chirico, the Dutch artist Mondrian, and the Russian Kandinsky. ${ }^{1}$

In an earlier study, I carried out a quantitative analysis of the careers of the most important painters of the early twentieth century who lived and worked in Paris. ${ }^{2}$ This paper provides a comparable analysis for the leading artists of this period whose careers were not primarily identified with Paris. Although most of the artists considered here did spend time working in Paris, the principal movements with which they were identified did not originate or develop there: prominent among them were Italy's Futurism, Germany's Blue Rider, Holland's De Stijl, and Russia's Suprematism. Although their specific goals differed greatly, these were all progressive movements that intended to produce new forms of art that were better suited to the modern world. These movements helped to make the early decades of the twentieth century a seminal period for modern art. Among their accomplishments was the creation of abstract painting, which would fundamentally affect how virtually all later artists, and their audiences, 
would approach art.

The Artists and the Data

The goal in choosing the artists to be studied here was to select the most important European painters who worked in the early twentieth century, excluding those considered in my earlier study. This was done using four leading textbooks on the history of modern art, published since $1970 .{ }^{3}$ Sixteen artists who were born outside France during 1860-90 and were not primarily identified with French artistic movements each had at least one painting reproduced in each of these four books. They are listed in Table 1.

The artists listed in Table 1 prominently include the three great pioneers of abstract painting - Kandinsky, Malevich, and Mondrian. They also include representatives of a large number of significant artistic movements of the period, including Die Brücke (Kirchner); the Blue Rider (Kandinsky and Marc); De Stijl (Mondrian); the Scuola Metafisica (de Chirico); Suprematism (Lissitzky and Malevich); Futurism (Balla, Boccioni, and Severini); and Dada (Schwitters). All of these movements built on or reacted against the innovations of Fauvism and Cubism that had occurred in Paris, but all of them were developed primarily outside France, in other major European cities.

Textbooks of art history also provide the evidence for this study. This was drawn from all available books, published in English since 1970, that contain illustrated surveys of modern art in the early twentieth century. A total of 44 such books were found. ${ }^{4}$ The data set for this study was created by listing every reproduction of every work of art shown in these books by all of the sixteen artists listed in Table 1.

$\underline{\text { Rankings and Puzzles }}$ 
Table 2 ranks the artists by total illustrations of their work in the books surveyed. Mondrian stands alone at the top, his important role in modern art indicated by an average of more than three illustrations of his work in the 44 books. Kandinsky and Malevich place second and third, each with more than two illustrations per book, followed by Klee, with nearly two per book.

The ranking of Table 2 may not appear surprising by itself, but a number of surprises and puzzles appear when it is considered together with Table 3, which ranks the top 20 individual works of the artists considered here, again by total appearances in the books surveyed. Several puzzles are posed just by the first entry in the table, which is the only work by any of the artists considered here to be reproduced in more than half of all the books examined. First, in spite of the fact that this study was designed to examine painters, Unique Forms of Continuity in Space is actually a sculpture. And second, it stands in first place in Table 3 in spite of the fact that its maker, Boccioni, ranks only seventh among the artists in Table 2, with less than half as many total illustrations as Mondrian. Boccioni’s performance in Table 3 more generally poses yet another puzzle, for he has more works listed - four - among the top 20 individual works than any other artist.

Mondrian's role in Table 3 is also puzzling, for in spite of his dominant position in Table 2, only two of his paintings appear among the top 20 individual works of Table 3 ; this ties him with de Chirico, who like Boccioni has less than half as many total illustrations in the textbooks as Mondrian. Furthermore, Mondrian's highest-ranked painting, Broadway Boogie-Woogie, ranks only seventh in Table 3 , behind works by six other artists. Curiously, also, Table 3 shows that Mondrian executed Broadway Boogie-Woogie when he was 71 years old. 
Another puzzling feature of Table 3 is the complete absence of any works by two of the four highest-ranked artists from Table 2. Thus neither Kandinsky nor Klee has a single work represented among the 20 most often reproduced works by the 16 artists in the sample. This means that neither had any painting reproduced in as many as six of the 44 books surveyed, in spite of the fact that this feat was accomplished by nine of the artists ranked below both of them in Table 2, including Severini, who had less than one-fifth as many total illustrations of his work as Kandinsky, and less than a quarter as many as Klee.

Comparing the positions of the three great artists who hold the highest positions in Table 2, it is intriguing that although Malevich stands significantly below both Mondrian and Kandinsky in total illustrations, he stands above both in producing important individual paintings. Thus Malevich has a painting that appears in more books than any work by either Mondrian or Kandinsky, and also has three paintings listed in Table 3, compared to two for Mondrian and none for Kandinsky.

Experimental and Conceptual Innovators

These puzzles can all be resolved through the use of an analytical framework that has been developed in earlier research. ${ }^{5}$ Doing so furthermore provides us with a richer understanding of these artists' careers, and of the nature of their work, than has previously been available.

The analytical framework divides artistic innovators into two groups. One of the groups proceeds experimentally, by trial and error, toward imprecise visual goals. Mondrian epitomizes these experimental innovators. Although his geometric compositions are often assumed to be the result of calculation, he stressed that this was never the case: "I believe that it is possible by 
means of horizontal and vertical lines, created consciously but not calculatingly, guided by a higher intuition and brought to harmony and rhythm... to arrive at a work of art which is as strong as it is true... And chance must be as far removed as calculation." ${ }^{\prime 6}$ The artist Harry Holtzman, who became a disciple of Mondrian's during the four years Mondrian spent in New York at the end of his life, testified that he worked visually and experimentally: "There was no program, no symbols, no 'geometry' or system of measure; only intuition determined the total rhythm of the relationship, by trial and error. The given space of the canvas, the given tension of its proportion, its size, were likewise experimentally determined and varied. Intuitive experience for Mondrian could only be direct, immediate, sensual."

As Holtzman suggested, the criteria that guided Mondrian's experimentation were aesthetic. An artist who knew him in Paris recalled watching him work in the 1920s: "if the black line was too thick, he'd take a piece of white paper, or a paper of about the same color as the color planes next to that line, and then he pasted it onto the canvas, and then held it at a distance to see 'is the line the way I want it or not."”8 Similarly, a friend from his last years in New York explained that Mondrian proceeded visually: "He tests each picture over a long period by eye: it is a physical adjustment of proportion through training, intuition, and testing."”

As is typical of experimental innovators, Mondrian's art developed gradually, over the course of decades. John Golding noted that from an early stage in his career he worked in series, indicating that he was concerned with themes rather than individual motifs. ${ }^{10}$ The critic Michel Seuphor, a friend of Mondrian's, recalled his extreme attention to detail, finding progress in changes so small that others might fail to notice: “'Even so, it's another step,' he once said to a friend who was studying a new picture of his, 'or don't you think so? Don't you find that it 
represents even a little step forward?""11 Mondrian's remarkable perseverance made the cumulative effect of his many incremental changes very great. David Sylvester observed that "A Mondrian retrospective is not just a procession of great pictures, but a progression which in itself is an aesthetic experience: the trajectory of the man's art becomes as much a thing of beauty as the art." ${ }^{\prime 2}$ Mondrian's extended search for new relationships between colors, and between shapes, may in fact have come to have a goal more complex than simply creating images. A scholar who studied the late work concluded that "Mondrian's painting practice in New York seems to reflect an accelerating doubt about whether it is possible, or even desirable, ever to finish a painting... Mondrian had not abandoned the idea of a product, just redefined it as a discovery or a solution, not a painting." ${ }^{, 13}$ Thus the painter Carl Holty wrote of visiting Mondrian’s New York studio: "Watching the pictures change into others as he worked, I asked him whether he wasn't losing good pictures in numbers because of his exigence. He said, 'I don't want pictures. I just want to find things out." ${ }^{\prime 14}$

Mondrian's position at the top of Table 2 is a consequence of his vast influence on the art of the twentieth century. This influence extended far beyond those painters who specifically emulated his goals and methods. One of his major roles was as an inspiration for abstract painters, even if they rejected the specific forms of his art. So for example Barnett Newman observed in 1945 that Mondrian's example "as artist and man has created respect for the steadfastness to principle" of abstract artists in general in the United States. ${ }^{15}$ Through De Stijl, Mondrian also had a great impact on modern architecture, for his forms inspired Walter Gropius, Mies van der Rohe, and the other architects who developed the International Style. ${ }^{16}$ In spite of the enormous overall importance of Mondrian's work, however, the absence of any of his 
paintings from the highest positions of Table 3 is a product of his experimental procedure. Like many experimental artists, Mondrian was a master without a dominant masterpiece: his innovations emerged gradually over an extended period, and were not declared in any individual work, so no single painting has clearly emerged as a defining image. ${ }^{17}$ A final puzzle about Mondrian concerns why the higher-ranked of his two paintings in Table 3 - Broadway BoogieWoogie, which ranks seventh overall - was made when he was 71 . The answer equally involves his experimental method. That painting, which was the last one Mondrian ever completed, combined a number of elements that he had developed and refined over the course of 30 years with several bold new devices. The result was striking, for in this late work Mondrian achieved both a new depth and a new dynamism. ${ }^{18}$ His ability to do this was a product of the wisdom he had gained through decades of research, based on both a profound knowledge of his art and an appreciation of the value of the willingness to experiment with significant new effects. Both his great expertise and his openness to new approaches were characteristics of the experimental nature of Mondrian's approach to art, for he was an experienced master who nonetheless realized that he could always go another step forward.

In contrast to the visual motivation of experimental artists, conceptual innovators formulate new methods intended to express their ideas or emotions, which can often immediately be embodied in novel works of art. Although these innovations are produced quickly, and can therefore occur at any stage of an artist's career, the most important conceptual advances tend to occur early, before the artist has become accustomed to, and therefore constrained by, fixed habits of thought. Boccioni offers an archetypal case of a conceptual innovator.

Boccioni was a young painter in 1909 when he and a few friends, including Giacomo 
Balla and Gino Severini, joined the Futurist movement, which had initially been founded by the poet F. T. Marinetti to reform literature. One of Marinetti's central themes was the beauty of speed, so a principal concern of the Futurist painters became the visual expression of the experience of motion. One of their goals was to portray movement as a process that occurred over time, while another was to represent the tendency of motion to destroy the concreteness of forms. Even before his conversion to Futurism, Boccioni had a conceptual inclination, as for example in 1907 he had complained to a friend that "I do not know how to transfer a literary or philosophical vision into a pictorial one."19 As a Futurist Boccioni followed a highly conceptual approach to art, declaring in a lecture in Rome in 1911 that "Art is not the copy of Nature," and explaining to a journalist that his goal was "to liberate myself from objective fact and arrive at an entirely spiritual expression: In me is the ultimate aspiration to try to reproduce the object as a sensation."20

Late in 1911 Boccioni visited Paris, where for the first time he saw Picasso's and Braque's radical innovations in Cubism, which he immediately adapted to Futurist ends in his paintings. While in Paris Boccioni apparently also became aware that there was not yet a Cubist school of sculpture, and that sculpture had consequently lagged behind painting in the development of advanced art. This provided an opportunity for him to make an immediate impact on the art world, and Boccioni wasted little time in doing this. Following a practice begun by Marinetti, Futurist artists had consistently used a novel conceptual device, in which polemical written manifestos accompanied, or even preceded, actual works of art. In keeping with this approach, in April of 1912 Boccioni published a manifesto proposing a Futurist sculpture that would create a sense of movement and eliminate the artificial separation of the object from its 
environment: "Let us fling open the figure and let it incorporate within itself whatever may surround it." After writing this call to arms, Boccioni proceeded to learn to make sculptures. ${ }^{21}$

A year later Boccioni exhibited 11 sculptures at a Paris gallery. His work was praised by Apollinaire, who noted the basis of the new sculptures in earlier experiments by Picasso, but nonetheless recognized their contribution: "Varied materials, sculptural simultaneity, violent movement - these are the innovations contributed by Boccioni's sculpture.” Apollinaire facetiously referred to Unique Forms of Continuity in Space as "muscles at full speed," but he also described it as a "joyful celebration of energy.",22

Boccioni ceased making sculptures after he executed Unique Forms; John Golding concluded that "with its completion, Boccioni seems to have realized that he had achieved the definitive masterpiece for which he longed."${ }^{, 23}$ Boccioni then returned to painting, in a much more conservative style, in the few years that remained before he was killed in 1916 while serving in the Italian army.

That Boccioni placed four works in Table 3 was not an accident, for it reflects his conceptual approach: the three ranked paintings were all carefully planned, with numerous preparatory studies, and their large sizes were indicative of Boccioni's conscious desire to have them make bold statements. So for example The City Rises of 1910, tied for tenth in Table 2, was preceded by at least a dozen preparatory drawings as well as a number of oil sketches. The painting was shown in a series of exhibitions throughout Europe to introduce the new art of Futurism, and for the occasion Boccioni made the painting no less than 64 square feet in size. Upon completing it, Boccioni wrote to a friend that he had intentionally produced a "masterwork" that represented the dynamism of the modern city. ${ }^{24}$ 
Boccioni's conceptual approach equally accounts for his ability to produce a sculpture that would become one of the most important individual works of art of the twentieth century in spite of the fact that he spent barely a year making sculptures, for like his paintings, Unique Forms was important primarily for its embodiment of new ideas. Although Boccioni was only 31 years old when he made his masterpiece, he believed he could have achieved much more, and at an even earlier age, had he had a better preparation in a more important artistic center. Thus in 1913, even as he wrote to a friend to tell him of the great success of his sculpture in Paris and of Apollinaire's enthusiastic support for Futurism, he added that in spite of his excitement he was "sad and discouraged," for "I think about what I would have done by now if I had grown up with Paris or Berlin as my environment." 25

That Kandinsky ranks second in Table 2, behind only Mondrian and well ahead of Malevich, but fails to appear in Table 3, implies that he produced an important body of work that is not dominated by one or two signature works. This suggests that he was an experimental innovator, and he clearly was. In a remarkable essay titled "Reminiscences," written when he was in his late 40s, Kandinsky described several key events in the development of his art. One of them occurred when he was 30, and contributed to his decision to abandon a career in law in favor of becoming an artist. At a Moscow exhibition, for the first time Kandinsky came upon a painting that was not strictly realistic: "That it was a haystack, the catalogue informed me. I didn't recognize it. I found this nonrecognition painful, and thought that the painter had no right to paint so indistinctly." But the painting had nonetheless seized his imagination:

I noticed with surprise and confusion that the picture not only gripped me, but impressed itself ineradicably upon my memory... I was not able to draw simple conclusions from this experience. 
What was, however, quite clear to me was the unsuspected power of the palette, previously concealed from me, which exceeded all my dreams. Painting took on a fairy-tale power and splendor. And, albeit unconsciously, objects were discredited as an essential element within the picture. ${ }^{26}$

Significantly, Kandinsky thus recalled that he was inspired by a visual event, as his first sight of a Monet not only led him to a recognition of the power of art, but also planted the realization that would eventually grow into a belief in the validity of abstraction, that objects were not essential elements of paintings.

The second episode occurred several years later, after Kandinsky had moved to Munich to study painting:

I was enchanted on one occasion by an unexpected spectacle that confronted me in my studio. It was the hour when dusk draws in. I returned home... and suddenly saw an indescribably beautiful picture, pervaded by an inner glow. At first, I stopped short and then quickly approached this mysterious picture, on which I could discern only forms and colors and whose content was incomprehensible. At once, I discovered the key to the puzzle: it was a picture I had painted, standing on its side against the wall.

This time, a purely visual experience led Kandinsky beyond his earlier recognition of the possibility of non-representational art, to an understanding of its desirability, for the next day, with his knowledge of the painting's representational contents, Kandinsky could not recreate his enchantment with the work. He drew a strong conclusion: "Now I could see clearly that objects harmed my pictures." 27

Kandinsky's pursuit of an abstract art therefore had empirical and visual origins. And because he was an experimental artist, that pursuit was based on visual criteria, and occurred cautiously and incrementally. Late in his life, he explained that he responded to the painting as it 
developed: “The artist 'hears' how something or other tells him: 'Hold it! Where? The line is too long. It has to be shortened, but only a little bit!' 'Just a little bit, I tell you!' Or: 'Do you want the red to stand out more? Good! Then add some green. Now they will "clash" a little. But only $a$ little, I tell you." This responsive process was essential: “One must have the perception to 'listen' when the voice sounds. Otherwise, no art.,"28

Kandinsky feared that a totally abstract art would degenerate into mere decoration, devoid of emotional or spiritual impact. He believed that non-representational art would remain meaningful only if it grew out of representation; if the artist began with objects, then veiled them by blurring or simplifying their forms, the spectator would sense their presence, and feel their impact, even if only subconsciously. Hidden images would lead viewers to participate in the creation of the work of art, as they moved from initial confusion to eventual understanding by deciphering the work's ambiguous forms. Making abstract art therefore involved hiding things: “concealment wields an enormous power in art." Even greater possibilities were raised by combining explicit and implicit forms, "the combination of the hidden and the revealed."29 Kandinsky's development of abstraction therefore involved a progression, as “objects began gradually to dissolve more and more in my pictures. This can be seen in nearly all the pictures of 1910." ${ }^{30}$ Will Grohmann's account of this process clearly explains that Kandinsky was not a conceptual innovator who worked decisively from ideas, but an experimental one who worked incrementally and visually:

It is only with the greatest caution that Kandinsky made the transition to abstract forms. Had he been guided by theory alone, he could easily, after he wrote On the Spiritual in Art (i.e. from 1910 onward), have completely eliminated naturalistic elements from his painting. In actual fact it took him four years to reach that 
point, and he was still painting landscapes as late as $1913 \ldots$ Since

Kandinsky was a visual type, extremely sensitive to optical impressions, ... he was compelled to express himself in sensory images. $^{31}$

Kandinsky recognized that his progress toward abstraction was slow. Thus in 1913 he observed that "Only after many years of patient toil and strenuous thought, numerous painstaking attempts... did I arrive at the pictorial forms I use today... I sometimes look back at the past and despair at how long this solution took me." ${ }^{32}$ Yet he understood that this process was required by the need for gradual learning: "it is impossible to conjure up maturity artificially at any particular time. And nothing is more damaging and more sinful than to seek one's forms by force... Thus, I was obliged to wait patiently for the hour that would lead my hand to create abstract form." 33

It was not only Kandinsky's style that evolved gradually, but also individual images. Just as the object in general dissolved slowly in his oeuvre, so specific objects disappeared in the process of creating individual paintings. Unlike most experimental artists, Kandinsky routinely made preparatory drawings and watercolors for his paintings. Unlike conceptual artists, however, for whom a painting is effectively an enlarged replica of a final preparatory work, Kandinsky's paintings are generally the last and most abstract stage of a progression, in which the image progressively became more abstracted from reality as each step gradually moved farther away from the recognizable representational forms of the first sketch. This process was described by Vivian Barnett:

In formulating the Improvisations between 1911 and 1913, the artist made preparatory watercolor sketches. By studying a group of related watercolors with the final oil version, it becomes clear that Kandinsky moved away from the object, obscuring the specific motif so only allusions to its representational origins are retained. Sometimes he executed a detailed watercolor study on which he 
based a canvas... In the large oil painting the forms have been obscured to an even greater degree than in the preparatory study. The images have been abstracted from nature to such an extent that they cannot easily be identified or "read."

Similarly, Rose-Carol Washton Long noted that whereas "In 1911 and 1912 most of his motifs are easily recognizable," Kandinsky's subsequent development of his abstract style meant that "the majority of [the] motifs in the works of middle and late 1912, 1913, and 1914 can be identified only with the help of sketches and earlier related works." 35

At the age of 50, Kandinsky wrote an essay dividing artistic talent into two types. One, the virtuoso, had a "brilliant, versatile" facility that manifested itself early, but was superficial and unoriginal, and failed to develop over time. In contrast, the creative artist had a unique vision that he pursued independently, refusing to conform to currently accepted standards. A consequence of the stubbornness and independence of the creative artist was that "in the beginning of their careers and often for many, many years, they are considered 'second class' artists." Yet later on, when an art historian looked back at the creative artist's career, he would see a straight line of growth, in which line and color "develop, purify, concentrate, and are brought to perfection." ${ }^{36}$ Nine years later, Kandinsky affirmed his belief in his own development over time, as he wrote to a friend that "I'd like to live, say, another fifty years to be able to penetrate art ever more deeply. We are really forced to stop much, much too early, at the very moment when we have begun to understand something. ${ }^{37}$ In a tribute to Kandinsky on the occasion of his $60^{\text {th }}$ birthday, his friend Paul Klee declared that "Many artists complete their work speedily (Franz Marc), others are able even in their fifties to take bold strides into unexplored territory and richly to develop the results they have achieved."38 
Klee was the other major painter considered here who failed to produce a single landmark work: thus although he ranks fourth in total illustrations in Table 2, none of his paintings appear in Table 3. Klee was an archetypal experimental painter, who believed that discovery was a crucial element in the process of making art. At the age of 30, he recorded in his diary that "in order to be successful, it is necessary never to work toward a conception of the picture completely thought out in advance. Instead, one must give oneself completely to the developing portion of the area to be painted." Five years later he returned to this theme, noting that the goal of a work was not a fixed point but a moving target because the process of creation was more important than the product: "In my productive activity, every time a type grows beyond the stage of its genesis, and I have about reached the goal, the intensity gets lost very quickly, and I have to look for new ways. It is precisely the way which is productive - this is the essential thing; becoming is more important than being." ${ }^{39}$ Klee taught at the Bauhaus during the 1920s, and "one of the foundations of his teaching was that no artist, and much less a student, should rely on ready-made forms... [H]e said to his pupils: 'You will never achieve anything unless you work up towards it. You can't break in halfway through the process, and least of all can you start with a result. You must start at the beginning. Then you will avoid all trace of artificiality, and the creative process will function without interruption.", 40

Nature was central to Klee's art. Thus he declared that "For the artist, dialogue with nature remains a conditio sina qua non." ${ }^{41}$ Observation was necessary. A student from the Bauhaus recalled that when Klee had asked the pupils to draw a leaf, his brief comments on the problem had made them feel that "we had never before seen a leaf, or rather the leaf, the essence of the leaf... [W]e had to admit that the first thing we had to do was to learn to see before we 
could draw another line." ${ }^{42}$ But observation alone was not sufficient, because Klee needed to reconcile nature with artistic form. Early in his career, he experimented with a device that might allow him to do this visually: "He drew faithfully from nature then turned his sheet of paper upside down and decided in the abstract on the form of the construction he was going to make. Then he turned the sheet of paper round again and proceeded to reconcile his construction with nature. ${ }^{, 43}$ Klee's goal was not simply to describe nature, but to do something more complex. He wanted to attain an understanding of nature's processes, and to use them as a basis for creating visual images: "For him, art was not simply parallel to creation; it was also a simile revealing it." ${ }^{44}$

Klee was not an expressionist, for his interest was neither in communicating the state of his own mind nor in declaring some unresolved conflict with society. ${ }^{45}$ Tellingly, Richard Verdi argues that Klee's approach shared more with the experimental Kandinsky than with their conceptual peers: "Klee's vision of nature has more in common with that of Kandinsky than of any other of his Expressionist contemporaries. In his abstract paintings of the period 1911-14 Kandinsky often evokes the world of microscopic creation and (as Klee himself would seek to do) calls to mind nature's formative processes rather than its finished forms." ${ }^{\text {"46 }}$ Both his interest in natural forms and his concern with creating visual representations of its processes made Klee's work a key influence on a number of Surrealist artists, including Ernst, Masson, and Miró. ${ }^{47}$

Table 4 shows the shortest period in each artist's career that contains at least half of the artist's total illustrations in the books surveyed.$^{48}$ The sudden breakthroughs of conceptual innovators mean that their most important work is often highly concentrated in time, and Boccioni's entry in Table 4 is a single year, that in which he executed Unique Forms of 
Continuity in Space. At the other extreme in the table is Mondrian, for whom no period of less than a decade contains at least half his total illustrations. Kandinsky (5 years) and Klee (9 years) also rank in the bottom half of the table. For all three of these great experimental artists, these particularly productive periods of their careers occurred after the age of 40 .

Like Boccioni, de Chirico produced the works that account for more than half of his total illustrations in a single year. He was then 26 years old. The Italian de Chirico arrived in Paris in 1911, at the age of 23, and during the next six years produced a series of strikingly original paintings in which he sought to give art the clarity "of the dream and of the child mind." ${ }^{49} \mathrm{De}$ Chirico called these works metaphysical, and the poet André Breton, the founder and leader of the Surrealist movement, considered them the most important twentieth-century inspiration for Surrealist painting. ${ }^{50}$ Thus Breton observed that "Chirico, in his youth, completed what was for us the most extraordinary journey ever taken," and compared the intensity of that episode to the meteoric career of a patron saint of Surrealist poetry: "Chirico's evolution during the four years when inspiration favored him above all others was just as headlong as that of Rimbaud during his equally brief career." ${ }^{, 51}$

Of de Chirico's classic paintings of 1911-17, he wrote that "I tried to express the strong and mysterious feeling I had discovered in the books of Nietzsche: the melancholy of beautiful autumn days, afternoons in Italian cities." 52 The inspiration for a painting arrived suddenly: "The revelation of a work of art... can be born of a sudden, when one least expects it, and also can be stimulated by the sight of something. ${ }^{, 53}$ But whatever the proximate stimulus, de Chirico was at pains to stress that his paintings were not intended merely to capture surface appearances, and that in fact "nobody has ever understood them, either then or now." ${ }^{4}$ In an early article, he 
explained that "Every serious work of art contains two different lonelinesses. The first might be called 'plastic loneliness,' this is, the beatitude of contemplation produced by the ingenious construction and combination of forms... The second loneliness is that of lines and signals; it is a metaphysical loneliness for which no logical training exists, visually or psychically. ${ }^{, 55} \mathrm{He}$ believed that he had the ability to see not only the appearance of objects "that is seen by people in general," but to capture "a spectral or metaphysical appearance beheld only by some rare individuals in moments of clairvoyance and metaphysical abstraction, as in the case of certain bodies concealed by substances impenetrable by sunlight yet discernible, for instance, by X-ray or other powerful artificial means." ${ }^{56}$

Like many conceptual artists, de Chirico could change his style abruptly. After serving in the Italian army in World War I, he remained in Italy. It was in Rome that he had an epiphany:

It was one morning at the Villa Borghese, in front of a painting by Titian, that I had a revelation of what great painting was: I saw tongues of fire appear in the gallery, while outside, beneath the clear sky over the city, rang out a solemn clangor as of weapons beaten in salute, and together with a great cry of righteous spirits there echoed the sound of a trumpet heralding a resurrection. ${ }^{57}$

De Chirico then began to devote much of his time to copying the works of old masters, and mimicking their styles. His change caused a bitter break with the Surrealists. In 1928 Breton declared that "We have spent five years now despairing of Chirico, forced to admit that he no longer has the slightest idea of what he is doing. " 58 James Soby believed that by the time of de Chirico's falling-out with Breton, "the hallucinatory intensity of his early art was spent," and expressed a widely held opinion when he stated that de Chirico's attempt to become a "living 'old master" " marked his "collapse... as an original, creative artist." ${ }^{\text {"59 }}$ Support for this view comes 
from the textbooks surveyed here. Remarkably, although they contain a total of 65 illustrations of de Chirico's work, only two of these are of paintings done after 1919. Art historians thus find virtually nothing of importance in the large body of work de Chirico produced in the final 57 years of his life. De Chirico, however, vigorously disagreed with these judgments. In his memoirs published in 1962, when he was 74, de Chirico denied he had ever discretely changed his style: "I have never had either a first or a second or a third or a fourth manner; I have always done what I wanted to do, standing loftily apart from the gossip and legends created about me by envious and interested people." Although he declared that he himself was probably the only one who could truly appreciate his artistic development, he believed that his career was a nearly unique case of steady growth:

If you think of all my exhibitions from 1918 until today you will see continual progress, a regular and persistent march towards those summits of mastery which were achieved by a few consummate artists of the past. Naturally, in order to see and say all this, one must have, in addition to my exceptional intelligence, so far as true painting is concerned, one must also have my mighty personality, my courage, and my ardent desire for truth. ${ }^{60}$

There was in fact nothing unique about de Chirico's sudden loss of creativity after a major early contribution, nor was it unique that he refused to acknowledge it; these are both common characteristics of the careers of many conceptual innovators. What was not common, however, was one of de Chirico's responses to this situation, as he effectively became a forger of his own early work. This curious practice may have begun in 1924, when the Surrealist poet Paul Eluard wanted to buy The Disquieting Muses, which de Chirico had painted in 1917. Eluard did not want to pay the high price asked by the Italian collector who owned the work, and de Chirico offered to make an "exact replica" of the painting for a lower price. Eluard accepted the offer and 
de Chirico promptly produced the replica. ${ }^{61}$ De Chirico appears to have continued to make copies of his famous early works in later years. ${ }^{62}$ His motives for doing this have never been fully understood, but a number of explanations have been suggested. One possibility is simply that he recognized that the market value of his early work was higher than that of later paintings, and that he therefore forged early paintings for financial gain. Another was that by successfully passing off later works as early ones, de Chirico was taking revenge on his enemies who praised only his early paintings, and was secretly proving for his own satisfaction that his skills had in fact not diminished. ${ }^{63}$ Whatever the true reason for his curious behavior, James Soby looked back at both de Chirico's decades of mediocre academic painting and his forgeries of his own early work and concluded that "de Chirico has tried with every means at his power to obliterate his own brilliant youth. Fortunately for the history of art he has failed. His early paintings survive and gain steadily in qualitative and historical importance." ${ }^{44}$

The peak period of Malevich's career identified in Table 4 consists of the four years in which he rapidly worked through the innovations of Cubism and Futurism and which culminated in his own remarkable innovation of a non-objective art that he named Suprematism. Malevich was a great conceptual innovator, and his career may have been the first major instance in modern art of a phenomenon that would become increasingly common later in the artistic globalization of the late twentieth century, in which a conceptual artist could assimilate and build on the advanced art of his time without any direct contact with the creators of that art. ${ }^{65}$

When Malevich moved to Moscow from his native Ukraine in 1907, he was already 29 years old. His exposure to advanced art began shortly thereafter, when he met a group of talented young Russian artists with whom he then worked and exhibited. He saw paintings by important 
French artists both in group exhibitions in Moscow and in the private collection of Sergei Shchukin, a wealthy Russian merchant who was a major early collector of Matisse, Picasso, Braque, and other young French artists. Malevich learned of the conceptual innovations of the Italian Futurists by reading the pamphlets published by Boccioni and his colleagues. As John Golding observed, these manifestos "were almost invariably blueprints for art that was about to be produced, ... and this explains why the influence of Italian Futurism was to be... entirely disproportionate to that of its artistic and intellectual achievements: it provided artists all over the world with instant aesthetic do-it-yourself kits."

Malevich's paintings from the years leading up to his 1915 departure into abstraction clearly show the direct influence of many advanced French and Italian painters, including Matisse, Picasso, Braque, Léger, Duchamp, and the Futurists, in spite of the fact that he had never worked with, or even met, any of these artists. That this was possible stemmed from the conceptual Malevich's ability quickly to learn the lessons of these conceptual artists simply by seeing their work, or reading their declarations. Even Malevich's radical leap of 1915, in which he dramatically launched the Suprematist movement, demonstrated his understanding of the process of conceptual innovation as it had developed in Western Europe. Thus not only did the flat geometric shapes of his abstract paintings reflect his analysis of the Synthetic Cubism of Picasso and Braque, but the paintings were accompanied by a Suprematist Manifesto that presented a complex intellectual rationale for the art works, revealing lessons Malevich had learned from the Futurists about the value of published statements in establishing new conceptual art movements. ${ }^{67}$

Malevich's mature work was based not only on careful planning but on explicit 
calculation. As early as 1911, both a gouache of a bather and a preparatory drawing for it reveal the presence of underlying grids drawn in pencil, indicating that the figure was transferred systematically from the drawing to the final work. ${ }^{68}$ John Milner observed that by 1913 "Malevich began to make the mathematical basis of his work a primary consideration," as he began to construct figures to fit predetermined geometric schemes. ${ }^{69}$ Milner notes that Malevich and his colleagues Lyubov Popova and Vladimir Tatlin "were all three constructing figures on the basis of geometry in 1913." Rather than beginning with a visual image, they were creating forms in order to satisfy specified conditions:

In preferring generalized construction to specific detail, and the approach of constructing with geometry, these painters relinquished the whole realist tradition. They moved beyond sensation by deleting or ignoring observed detail. They used their eyes to measure the geometric forms with which they constructed, not to record the incidental forms that happened to fall within their gaze. These were the building tools of the new perspectives and proportions, the sign and purpose of which was ultimately rhythm. ${ }^{70}$

Malevich's reliance on mathematics continued throughout his key period: Golding observed that "Malevich had always been interested in geometry but it is now, between 1913 and 1915, that it becomes for him an obsessive concern." "71 Geometry not only underlay the forms of the paintings Malevich displayed at the landmark "0, 10" exhibition in December, 1915, at which he first presented his Suprematist compositions, but it was even used to determine the arrangement of the paintings on the walls. ${ }^{72}$ In an essay completed just before the exhibition opened, Malevich declared that the square "is the first step of pure creation in art." Malevich's Suprematism developed rapidly in the years after 1915, from relatively simple compositions to more complex works. Golding recognized that this speed was a function of the 
conceptual nature of the art: "During the years following the launch of the Suprematist Manifesto Malevich's thought was evolving at the same dizzying and heady rate as the evolution of his painting itself. His intellectual sources... are astonishingly and bafflingly disparate." ${ }^{" 74}$ Malevich acknowledged the conceptual basis of his art, as in 1919 he declared "The important thing in art is signs flowing from the creative brain.," 75

The foundation of experimental art in the process of trial and error means that experimental innovators rarely reach absolute roadblocks: their experiments may not always produce significant new results, but it is rare that they cannot formulate a next step to take. The same is not true for conceptual innovators, who may simply run out of new ideas. Many conceptual artists deal with this problem by effectively repeating their earlier advances, but some of the greatest ones, including Duchamp and Picasso, apparently resisted this, and consequently went through periods of artistic inactivity. Malevich apparently belonged to this latter group, for he ceased painting for five years after producing the Suprematist White paintings, the most famous of which is Malevich's highest-ranked entry in Table 3. Golding remarked on this:

Malevich is the true father of what we have come to call "minimal" and "conceptual" art. But he is also the prototype for countless subsequent abstract artists who having reached their goal - or at least a distillation of the ideas and sensations they were seeking to evoke - only find themselves in the tragic position of wondering how to go further, how to avoid the endless repetition of the climax of their achievement, a repetition that might ultimately only drain their art of much of its original impact or meaning. Mondrian knew how to renew himself by constantly kicking the visual ladder from under himself. Kandinsky's endlessly inquiring mind produced for him, throughout his career, a succession of alternative possibilities. Malevich had succumbed to the principle of destruction inherent in a Hegelian system of dialectics. ${ }^{76}$

Golding's observation can be explained simply: conceptual innovators can fully express their 
ideas, and thus reach their goals, but experimental innovators generally do not believe in definitive conclusions. The vague goals of Kandinsky and Mondrian never allowed them to feel satisfied that they had reached a conclusion, but Malevich's theoretical demonstrations of his ideas left him with no further problems to solve.

Table 5 shows each painter's age in the single year from which the textbooks contain the most illustrations. The conceptual artists de Chirico, Boccioni, and Malevich were 26, 31, and 37, respectively, in these best years, whereas the experimental Mondrian, Klee, and Kandinsky were all older, at 40, 43, and 47, respectively, when they reached their peaks.

Munch's entry in Table 5 is for 1893 , when he was 30 . This was the year he painted The Scream, which ranks second in Table 3 and which has become one of the most famous images in modern art for its vivid representation of psychological distress. The dramatic expression of the horror experienced by the painting's androgynous central figure is achieved not only by that figure's own actions, with its mouth opened wide in fear and its hands pressed to the sides of its head, but also through exaggeration and distortion: the figure's head is little more than a skull, the sunset is painted in garish reds and yellows, and the landscape behind the figure is contorted in broad curves. The painting has long been recognized as "the quintessential picture of [Munch's] career," the most powerful achievement of the style that made Munch a central influence on the expressionism of the twentieth century. ${ }^{77}$

As a young artist in Norway, Munch entered a profession in which the goal of the leading members was to paint nature in a realistic manner. Munch learned their methods, but was dissatisfied by his inability to use them to express his emotions. A major change in his art began when he went to live in Paris in 1889 at the age of 26 . There for the first time he saw the art of 
the Post-Impressionists, and their conceptual approach gave him the means to break with his realist training. Soon he could declare that "how you see is also dependent on your emotional state." He named his new approach Symbolism, which he defined: "Nature is transformed according to one's subjective disposition." 78

In 1891, Munch wrote that his paintings were "designed to move people intensely."79 In January 1892 , he recorded in his diary an intense experience:

I was walking along the road with two friends. The sun set. I felt a tinge of melancholy. Suddenly the sky became bloody red.

I stopped, leaned against the railing, dead tired and I looked at the flaming clouds that hung like blood and a sword over the blue-black fjord and city.

My friends walked on. I stood there, trembling with fright. And I felt a loud, unending scream piercing nature. ${ }^{80}$

Munch illustrated this account with a sketch. He wanted to paint this memory, but a friend recalled that he was frustrated because he feared others wouldn't see it in the same way he had: "He was in despair because the miserable means available to painting were not sufficient." ${ }^{81}$ Yet he was determined to try nonetheless, and over the course of the next few years he made a series of preparatory sketches and drawings. As he worked the scene became more stylized, more conceptualized, and less detailed. Munch worked on no other composition for at least a year before he executed the final version of The Scream. He recognized that it was an important achievement, and he continued to use the symbolic formulas from the painting in later works. ${ }^{82}$ Munch continued to work for more than 50 years after painting The Scream, and during his lifetime he came to be widely recognized as the greatest artist in Norway's history. Yet he never again approached the importance of the conceptual breakthrough he had made as a young artist, in creating new visual means for expressing a state of mind. 
Table 5 shows that Kirchner's best year came at the age of 33. German Expressionism first appeared in 1905 when a group of young artists in Dresden formed a group called Die Brücke, or the Bridge. Kirchner was the leading member of the group, which was dedicated to a search for self-expression, using contemporary subjects to express the anxiety of their time. Early in his career, Kirchner had discovered that quick sketches of moving figures produced more convincing representations than more painstaking and careful compositions, in spite of the abbreviations and departures from realism involved in the sketches: "I was struck with astonishment: there was after all a form which could represent, say, a man or a movement exactly and for all that depart from the objective form in nature... Was it perhaps possible in this manner to produce an art, understandable to all (though not their ideal in photographic faithfulness to nature) - an art in a language of symbolic form?" ${ }^{93}$ In its mature form, his expressionist art was based on illusion: "Without imagination there is no art; it is the source."

Kirchner's subjective art was not intended to describe reality, but to create a new reality. In the words of a friend and biographer, "Kirchner saw the world not as it is, but transformed through his emotion. He built emotionally colored mental images into things and assigned them the role of carrying his inner experiences." ${ }^{85}$ His most famous works, made when he was in his late 20 s and early 30 s, use exaggerations of color and form to portray the decadence of Berlin's street life on the eve of World War I.

Table 6 provides a measure of the temporal concentration of each artist's contribution, by showing the share of the artist's total illustrations accounted for by works made in his single best year. The sudden and discrete achievements of conceptual artists mean that their peaks typically occur not only earlier in their careers but also more suddenly, and the evidence of Table 6 reflects 
this, with the five conceptual artists all ranked above the three experimental innovators in the table. Remarkably for important artists, both Boccioni and de Chirico derived more than half of their total illustrations from the work of a single year. In contrast, at the opposite end of the spectrum neither Klee nor Mondrian derived as many as a fifth of their total illustrations from the paintings of any one year.

The concentration of these artists' work in a different dimension is summarized by Table 7, which shows the percentage of each artist's total illustrations that are accounted for by the $10 \%$ of his paintings that are most often reproduced. So for example 27 different paintings by Munch appear in the textbooks, reproduced a total of 68 times; three of the paintings account for 35 of these illustrations, so Munch's entry in Table 7 is $52 \%$.

Table 7 shows that the greatest inequality in the distribution of artists' illustrations across paintings also occurs for the conceptual artists, whose innovations are often announced and embodied in individual breakthrough works. The five major conceptual artists considered here thus occupy the top five positions in the table. In contrast, experimental artists' careers are not generally dominated by individual masterpieces. Mondrian, Klee, and Kandinsky are ranked in the three lowest positions in the table, demonstrating a relative lack of agreement on which of their works best represent their major contributions.

Each of the eight major artists considered in this study had more than two years from which their work was illustrated at least five times; thus by this measure all made significant contributions in a number of different years. Table 8 presents the interval that elapsed between the earliest and latest of these significant years for each artist.

Mondrian stands far above all the others, as his interval of 35 years between earliest and 
latest significant years is nearly double that of any other artist in the table. Kirchner, Klee, and Kandinsky in turn each stand far above Munch and Malevich, while the shortest intervals in the table are those for de Chirico and Boccioni. Thus only Kirchner deviates from the pattern that the elapsed periods over which the experimental innovators made significant contributions were considerably longer than the innovative periods in the careers of the conceptual artists.

Table 8 also serves to provide an overview of the eight artists' careers, by showing the ages when they made their earliest and latest significant contributions. For the five conceptual painters the earliest contributions occurred from ages 25-34, and their latest contributions from 29-46. The three experimental painters all began later, with their first contributions from 36-43, and they all finished considerably later, from 59-71. The prime periods for the contributions of the conceptual painters were generally in their late 20 s and their 30 s, whereas those for the experimental painters were generally in their 40s and 50s. The greatest conceptual painter in this study, Malevich, made his significant contributions during his late 30s, whereas the greatest experimental painter, Mondrian, made his significant contributions from 36 to 71, or during the entire second half of his life. Overall, the innovative periods in the careers of the experimental innovators occurred considerably later in their lives than those of the conceptual artists.

\section{$\underline{\text { Conclusion }}$}

One of the facts that is underlined most forcefully by this investigation is the remarkable concentration of artistic innovations that occurred in roughly the five years preceding the outbreak of World War I. Among the important artists who made major advances in this period were Boccioni, de Chirico, Kirchner, Kandinsky, Malevich, and Mondrian. In part, this reflects the enormous impact of the invention and development of Cubism from 1907 on, as Boccioni, 
Malevich, and Mondrian were all strongly affected by Cubism, as was Klee. But even independent of Cubism, the half decade that began in 1910 also was the setting for the origins of visual Surrealism in the work of de Chirico, the development of German Expressionism in the work of Kirchner and his colleagues, and the evolution of Kandinsky's form of abstract art. The remarkable speed of the diffusion of Cubism, and the suddenness of the appearance of the innovations of Boccioni, de Chirico, Kirchner, and Malevich, also clearly reflect the conceptual nature of these new styles and art forms.

A number of studies of modern artists have shown that conceptual innovators generally make their greatest contributions early in their careers, whereas experimental artists typically improve with age, and do their best work late in their careers. The artists considered here clearly fit these patterns. The conceptual artists Boccioni, de Chirico, Kirchner, and Munch all produced their major contributions before the age of 35. Even Malevich, who did not see advanced art until he was nearly 30, and who never had direct contact with the advanced artists of his time, developed sufficiently rapidly that he produced his major work before the age of 40 . In contrast, the great experimental painters Klee, Kandinsky, and Mondrian all produced their most important work after the age of 40, and all three continued to make significant contributions after 50. Mondrian, the greatest of them, executed his greatest painting - the last one he would ever complete - at the age of 71, just months before his death.

The quantitative analysis carried out in this study has also resolved a number of puzzles, some of which had previously been noted by art historians. An important example concerns differences in the paths that Kandinsky, Malevich, and Mondrian followed in creating their innovations of abstract art. A clear formulation of the difference was offered by John Golding, 
who observed that "It might be fair to say that Malevich's abstraction sprang, Athena-like, ready formed from the brow of its creator; this distinguishes Malevich's approach very sharply from that of both Mondrian and Kandinsky, who had sensed and inched their way into abstraction over a period of many years." ${ }^{86}$ Golding offered no explanation for this contrast, but this investigation has shown that it is clearly rooted in the difference between the conceptual method of Malevich, who could make radical leaps of innovation as his ideas were formulated, and the experimental methods of Kandinsky and Mondrian, who both advanced slowly, by trial and error, based on visual inspection of the appearance of their paintings. That the epoch-making invention of abstract art was made nearly simultaneously by both conceptual and experimental innovators is yet another demonstration of the central importance of both deductive and inductive approaches in the history of modern art. 


\section{$\underline{\text { Footnotes }}$}

I thank Robert Jensen for discussions of the issues treated in this paper, Peter Northup for research assistance, and the National Science Foundation for financial support.

1. Apollinaire 2001, pp. 267-70.

2. Galenson 2002.

3. Hamilton 1972; Arnason 1986; Hunter 1992; Bowness 1995.

4. The books used are listed in the appendix.

5. E.g. see Galenson 2001.

6. Blotkemp 1995, p. 81.

7. Cooper and Spronk 2001, p. 18.

8. Cooper and Spronk 2001, p. 49.

9. Seuphor 1956, p. 181.

10. Golding 2000, pp. 12-13.

11. Seuphor 1956, pp. 151, 198.

12. Sylvester 1997, p. 434.

13. Cooper and Spronk, pp. 53-54.

14. Holty 1957, p. 21.

15. Newman 1992, p. 155.

16. Scully 2003, p. 80.

17. For other examples of artists of this kind, see Galenson 2002.

18. For discussion see Galenson 2004.

19. Coen 1988, p. xix.

20. Coen 1988, pp. xxiii, 234. 
21. Golding 1972, pp. 12-22; Coen 1988, pp. 240-43.

22. Apollinaire 2001, pp. 320-21.

23. Golding 1972, p. 28.

24. Coen 1988, pp. 94-104.

25. Coen 1988, p. 204.

26. Kandinsky 1994, p. 363.

27. Kandinsky 1994, pp. 369-70.

28. Kandinsky 1994, p. 799.

29. Kandinsky 1994, pp. 170-71; Long 1980, 66.

30. Kandinsky 1994, p. 396.

31. Grohmann 1958, p. 145.

32. Kandinsky 1994 p. 370.

33. Kandinsky 1994, p. 396.

34. Barnett 1983, pp. 29-30.

35. Long 1980, p. 74.

36. Kandinsky 1994, pp. 414-15.

37. Grohmann 1958, p. 200.

38. Grohmann 1958, p. 201.

39. Klee 1964, pp. 236, 307.

40. Haftmann 1967, p. 83.

41. Verdi 1984, p. 17.

42. Verdi 1984, p. 25.

43. Haftmann 1967, p. 42.

44. Haftmann 1967, p. 117. 
45. Verdi 1984, p. 212.

46. Verdi 1984, pp. 215-16.

47. Verdi 1984, p. 216.

48. Table 4 and subsequent tables are restricted to the most important artists in the sample, defined as those with an average of more than one illustration per book surveyed.

49. Soby 1966, p. 42.

50. Soby 1966, p. 161.

51. Breton 2002, pp. 16, 63.

52. de Chirico 1994, p. 61.

53. Soby 1966, p. 251.

54. de Chirico 1994, p. 67.

55. Soby 1966, p. 66.

56. Soby 1966 , p. 67.

57. de Chirico 1944, pp. 96-97.

58. Breton 2002, p. 13.

59. Soby 1966, pp. 157, 161.

60. de Chirico 1994, pp. 170, 225.

61. Soby 1966, p. 134.

62. E.g. see Soby 1966, pp. 43, 50, 68, 132.

63. These two explanations are not exclusive; see Crosland 1999, p. 97.

64. Soby 1966, p. 162.

65. For discussion see Galenson 2006, Chapter 4.

66. Golding 2000, pp. 48-53.

67. Golding 2000, pp. 47-58. 
68. Milner 1996, p. 21.

69. Milner 1996, pp. 60-63.

70. Milner 1996, pp. 80-81.

71. Golding 2000, p. 62.

72. Milner 1996, p. 124.

73. Milner 1996, p. 125.

74. Golding 2000, p. 74.

75. Golding 2000, p. 76.

76. Golding 2000, p. 78.

77. Hamilton 1972, pp. 124-27.

78. Heller 1984, p. 66.

79. Heller 1972, p. 23.

80. Heller 1972, p. 107.

81. Heller 1984, p. 82.

82. Heller 1972, pp. 71-95.

83. Gordon 1968, p. 19.

84. Gordon 1968, p. 25.

85. Grohmann 1961, p. 50.

86. Golding 2000, p. 67. 


\section{$\underline{\text { References }}$}

Apollinaire, Guillaume. 2001. Apollinaire on Art. Boston: MFA Publications.

Arnason, H. H. 1986. History of Modern Art, 3d ed. New York: Harry N. Abrams.

Barnett, Vivian. 1983. Kandinsky at the Guggenheim. New York: Abbeville Press.

Blotkamp, Carel. 1995. Mondrian. New York: Harry N. Abrams.

Bowness, Alan. 1995. Modern European Art. New York: Thames and Hudson.

Breton, André. 2002. Surrealism and Painting. Boston: MFA Publications.

Coen, Ester. 1988. Umberto Boccioni. New York: Metropolitan Museum of Art.

Cooper, Harry, and Ron Spronk. 2001. Mondrian. New Haven: Yale University Press.

Crosland, Margaret. 1999. The Enigma of Giorgio de Chirico. London: Peter Owen.

de Chirico, Giorgio. 1994. The Memoirs of Giorgio de Chirico. New York: Da Capo Press.

Galenson, David. 2001. Painting outside the Lines. Cambridge: Harvard University Press.

Galenson, David. 2002. "Quantifying Artistic Success: Ranking French Painters - and Paintings from Impressionism to Cubism." Historical Methods. Vol. 35, No. 1 (Winter), pp. 5-20.

Galenson, David. 2004. "A Portrait of the Artist as a Very Young or Very Old Innovator: Creativity at the Extremes of the Life Cycle." NBER Working Paper 10515.

Galenson, David. 2006. Old Masters and Young Geniuses: The Two Life Cycles of Artistic Creativity. Princeton: Princeton University Press.

Golding, John. 1972. Boccioni's “Unique Forms of Continuity in Space." Newcastle: University of Newcastle upon Tyne.

Golding, John. 2000. Paths to the Absolute. Princeton: Princeton University Press.

Gordon, Donald. 1968. Ernst Ludwig Kirchner. Cambridge: Harvard University Press.

Grohmann, Will. 1958. Wassily Kandinsky. New York: Harry N. Abrams.

Grohmann, Will. 1961. E. L. Kirchner. New York: Thames and Hudson.

Haftmann, Werner. 1967. The Mind and Work of Paul Klee. New York: Frederick A. Praeger. 
Hamilton, George Heard. 1972. Painting and Sculpture in Europe 1880-1940. Harmondsworth: Penguin.

Heller, Reinhold. 1972. Edvard Munch: The Scream. New York: Viking Press.

Heller, Reinhold. 1984. Munch. Chicago: University of Chicago Press.

Holty, Carl. 1957. “Mondrian in New York: A Memoir.” Arts, Vol. 31, No. 10, pp. 17-21.

Hunter, Sam, and John Jacobus. 1992. Modern Art, 3d ed. Englewood Cliffs: Prentice-Hall.

Kandinsky, Wassily. 1994. Kandinsky, Complete Writings on Art. New York: Da Capo Press.

Klee, Paul. 1964. The Diaries of Paul Klee, 1898-1918. Berkeley: University of California Press.

Long, Rose-Carol. 1980. Kandinsky. Oxford: Clarendon Press.

Milner, John. 1996. Kazimir Malevich and the Art of Geometry. New Haven: Yale University Press.

Newman, Barnett. 1992. Barnett Newman. Berkeley: University of California Press.

Scully, Vincent. 2003. Modern Architecture and Other Essays. Princeton: Princeton University Press.

Seuphor, Michel. 1956. Piet Mondrian. New York: Harry N. Abrams.

Soby, James. 1966. Giorgio de Chirico. New York: Arno Press.

Sylvester, David. 1997. About Modern Art. New York: Henry Holt.

Verdi, Richard. 1984. Klee and Nature. New York: Rizzoli. 
Appendix: The books surveyed for this study are listed here, ordered by date of publication.

1. Hamilton, George Heard. 1970. 19th and 20th Century Art. New York: Harry N. Abrams.

2. Cleaver, Dale. 1972. Art., second ed. New York: Harcourt Brace-Jovanovich.

3. Ruskin, Ariane. 1974. History in Art. New York: Franklin Watts.

4. Spencer, Harold. 1975. The Image Maker. New York: Charles Scribner's Sons.

5. Lynton, Norbert. 1980. The Story of Modern Art. Ithaca: Cornell University Press.

6. Hughes, Robert. 1980. The Shock of the New. New York: Alfred A. Knopf.

7. Russell, John. 1981. The Meanings of Modern Art. New York: Museum of Modern Art.

8. Canaday, John. 1981. Mainstreams of Modern Art, second ed. Fort Worth: Harcourt Brace Jovanovich.

9. Cornell, Sara. 1983. Art. Englewood Cliffs: Prentice-Hall.

10. Collins, Judith; John Welchman; David Chandler; and David Anfam. 1983. Techniques of Modern Artists. London: Macdonald.

11. Sporre, Dennis. 1984. The Arts. Englewood Cliffs: Prentice-Hall.

12. Britsch, Ralph; and Todd Britsch. 1984. The Arts in Western Culture. Englewood Cliffs: Prentice-Hall.

13. Feldman, Edmund. 1985. Thinking About Art. Englewood Cliffs: Prentice-Hall.

14. Arnason, H. H.; and Daniel Wheeler. 1986. History of Modern Art, third ed. New York: Harry N. Abrams.

15. Muller, Joseph-Emile; and Ramon Tio Bellido. 1986. A Century of Modern Painting. New York: Universe Books.

16. Honour, Hugh; and John Fleming. 1986. The Visual Arts, second ed. Englewood Cliffs: Prentice-Hall.

17. de la Croix, Horst; Richard Tansey; and Diane Kirkpatrick. 1987. Gardner's Art Through the Ages, ninth ed. San Diego: Harcourt Brace Jovanovich.

18. Hartt, Frederick. 1989. Art, third ed. Englewood Cliffs: Prentice-Hall. 
19. Wood, Michael; Bruce Cole; and Adelheid Gealt. 1989. Art of the Western World. New York: Simon and Schuster.

20. Varnedoe, Kirk. 1990. A Fine Disregard. New York: Harry N. Abrams.

21. Yenawine, Philip. 1991. How to Look at Modern Art. New York: Harry N. Abrams.

22. Tamplin, Ronald. 1991. The Arts. Oxford: Oxford University Press.

23. Hunter, Sam; and John Jacobus. 1991. Modern Art, third ed. Englewood Cliffs: PrenticeHall.

24. Strickland, Carol; and John Boswell. 1992. The Annotated Mona Lisa. Kansas City: Andrews and McMeel.

25. Three books treated as one:

Frascina, Francis; Nigel Blake; Briony Fer; Tamar Garb; and Charles Harrison. 1993. Modernity and Modernism. New Haven: Yale University Press.

Harrison, Charles; Francis Frascina; and Gill Perry. 1993. Primitivism, Cubism, Abstraction. New Haven: Yale University Press.

Fer, Briony; David Batchelor; and Paul Wood. 1993. Realism, Rationalism, Surrealism. New Haven: Yale University Press.

26. Silver, Larry. 1993. Art in History. Englewood Cliffs: Prentice-Hall.

27. Adams, Laurie. 1994. A History of Western Art. New York: Harry N. Abrams.

28. Stangos, Nikos. 1994. Concepts of Modern Art, third ed. London: Thames and Hudson.

29. Bowness, Alan. 1995. Modern European Art. New York: Thames and Hudson.

30. Stokstad, Marilyn. 1995. Art History. New York: Harry N. Abrams.

31. Wilkins, David; Bernard Schultz; and Katheryn Linduff. 1997. Art Past, Art Present. New York: Harry N. Abrams.

32. Lucie-Smith, Edward. 1997. Visual Arts in the Twentieth Century. New York: Harry N. Abrams.

33. Gebhardt, Volker. 1998. The History of Art. New York: Barron's

34. Freeman, Julian. 1998. Art. New York: Watson-Guptill. 
35. Ruhrberg, Karl. 1998. Art of the $20^{\text {th }}$ Century, Vol. 1. Cologne: Taschen.

36. Fleming, William. 1995. Arts and Ideas, ninth ed. Fort Worth: Harcourt Brace.

37. Britt, David. 1999. Modern Art. New York: Thames and Hudson.

38. Bocola, Sandro. 1999. The Art of Modernism. Munich: Prestel.

39. Lucie-Smith, Edward. 1999. Lives of the Great Twentieth-Century Artists. London: Thames and Hudson.

40. Preble, Duane; Sarah Preble; and Patrick Frank. 1999. Artforms, sixth ed. New York: Longman.

41. Kemp, Martin. 2000. The Oxford History of Western Art. Oxford: Oxford University Press.

42. Collings, Matthew. 2000. This is Modern Art. New York: Watson-Guptill.

43. Parmesani, Loredana. 2000. Art of the Twentieth Century. Milan: Skira.

44. Bell, Cory. 2001. Modern Art. New York: Watson-Guptill. 
Table 1: Artists Included in this study

\begin{tabular}{|l|c|c|c|}
\hline Artist & Country of birth & Year of birth & Year of death \\
\hline \hline Balla, Giacomo & Italy & 1871 & 1958 \\
\hline Boccioni, Umberto & Italy & 1882 & 1916 \\
\hline de Chirico, Giorgio & Italy & 1888 & 1976 \\
\hline Kandinsky, Wassily & Russia & 1866 & 1944 \\
\hline Kirchner, Ernst & Germany & 1880 & 1938 \\
\hline Klee, Paul & Switzerland & 1879 & 1940 \\
\hline Kokoschka, Oscar & Austria & 1886 & 1980 \\
\hline Kupka, Frantisek & Czechoslovakia & 1871 & 1957 \\
\hline Lissitzky, El & Russia & 1890 & 1941 \\
\hline Malevich, Kasimir & Russia & 1878 & 1935 \\
\hline Marc, Franz & Germany & 1880 & 1916 \\
\hline Mondrian, Piet & Holland & 1872 & 1944 \\
\hline Munch, Edvard & Norway & 1863 & 1944 \\
\hline Nolde, Emile & Germany & 1867 & 1953 \\
\hline Schwitters, Kurt & Germany & 1887 & 1948 \\
\hline Severini, Gino & Italy & 1883 & \\
\hline
\end{tabular}

Source: see text. 
Table 2: Ranking of Artists by Total Illustrations

\begin{tabular}{|c|l|c|}
\hline Rank & Artist & $\mathrm{n}$ \\
\hline \hline 1 & Mondrian & 142 \\
\hline 2 & Kandinsky & 118 \\
\hline 3 & Malevich & 89 \\
\hline 4 & Klee & 87 \\
\hline 5 & Kirchner & 71 \\
\hline 6 & Munch & 68 \\
\hline 7 & Boccioni & 67 \\
\hline 8 & de Chirico & 65 \\
\hline 9 & Balla & 42 \\
\hline 10 & Lissitzky & 38 \\
\hline 11 & Schwitters & 35 \\
\hline 12 & Marc & 34 \\
\hline 13 & Nolde & 34 \\
\hline 14 & Kokoschka & 19 \\
\hline 15 & Severini & \\
\hline 16 & Kupka & 28 \\
\hline
\end{tabular}

Source: $\quad$ This and subsequent tables are based on the data set constructed for this study. See text for description, and appendix for references. 
Table 3: Ranking of Art Works by Total Illustrations

\begin{tabular}{|c|c|c|c|c|}
\hline Rank & $\mathrm{n}$ & Artist, title & Date & Location \\
\hline 1 & 24 & $\begin{array}{l}\text { Boccioni, Unique Forms of Continuity in } \\
\text { Space }\end{array}$ & 1913 & New York \\
\hline 2 & 20 & Munch, The Scream & 1893 & Oslo \\
\hline 3 & 15 & Balla, Dynamism of a Dog on a Leash & 1912 & Buffalo \\
\hline $4 \mathrm{t}$ & 13 & $\begin{array}{l}\text { de Chirico, Mystery and Melancholy of a } \\
\text { Street }\end{array}$ & 1914 & $\begin{array}{l}\text { Private } \\
\text { collection }\end{array}$ \\
\hline $4 \mathrm{t}$ & 13 & Kirchner, Berlin Street Scene & 1913 & New York \\
\hline 6 & 12 & $\begin{array}{l}\text { Malevich, Supremalist Composition, White on } \\
\text { White }\end{array}$ & 1918 & New York \\
\hline 7 & 11 & Mondrian, Broadway Boogie-Woogie & 1943 & New York \\
\hline 8 & 10 & Kokoschka, The Tempest & 1914 & Basel \\
\hline 9 & 9 & Munch, Puberty & 1894 & Oslo \\
\hline $10 \mathrm{t}$ & 8 & Boccioni, The City Rises & 1910 & New York \\
\hline $10 \mathrm{t}$ & 8 & Boccioni, The Dynamism of a Soccer Player & 1913 & New York \\
\hline $10 \mathrm{t}$ & 8 & Marc, Blue Horses & 1911 & Minneapolis \\
\hline $10 t$ & 8 & $\begin{array}{l}\text { Mondrian, Composition No. 10: Pier and } \\
\text { Ocean }\end{array}$ & 1915 & Otterlo \\
\hline $14 \mathrm{t}$ & 7 & Boccioni, States of Mind: The Farewells & 1911 & New York \\
\hline $14 t$ & 7 & Lissitzky, Proun 99 & 1924 & New Haven \\
\hline $16 \mathrm{t}$ & 6 & de Chirico, Song of Love & 1914 & New York \\
\hline $16 \mathrm{t}$ & 6 & $\begin{array}{l}\text { Malevich, Suprematist Composition: Airplane } \\
\text { Flying }\end{array}$ & 1915 & New York \\
\hline $16 t$ & 6 & $\begin{array}{l}\text { Malevich, Suprematist Painting (Eight Red } \\
\text { Rectangles) }\end{array}$ & 1915 & Amsterdam \\
\hline $16 \mathrm{t}$ & 6 & Munch, The Dance of Life & 1900 & Oslo \\
\hline $16 \mathrm{t}$ & 6 & $\begin{array}{l}\text { Severini, Dynamic Hieroglyphic of the Bal } \\
\text { Tabarin }\end{array}$ & 1912 & New York \\
\hline
\end{tabular}


Table 4: $\quad$ Shortest Periods that Contain at Least Half an Artist's Total Illustrations

\begin{tabular}{|l|c|c|c|c|}
\hline Artist & Number of years & Dates & Ages & $\mathrm{n}$ \\
\hline \hline Boccioni & 1 & 1913 & 31 & 37 \\
\hline de Chirico & 1 & 1914 & 26 & 34 \\
\hline Munch & 3 & $1893-95$ & $30-32$ & 43 \\
\hline Malevich & 4 & $1912-15$ & $34-37$ & 47 \\
\hline Kandinsky & 5 & $1910-14$ & $44-48$ & 65 \\
\hline Kirchner & 5 & $1909-13$ & $29-33$ & 40 \\
\hline Klee & 9 & $1922-30$ & $43-51$ & 46 \\
\hline Mondrian & 10 & $1912-21$ & $40-49$ & 74 \\
\hline
\end{tabular}


Table 5: Artist's Age in Year Represented by Most Illustrations

\begin{tabular}{|l|c|c|c|}
\hline Artist & Year & $\mathrm{n}$ & Age \\
\hline \hline de Chirico & 1914 & 34 & 26 \\
\hline Munch & 1893 & 23 & 30 \\
\hline Boccioni & 1913 & 37 & 31 \\
\hline Kirchner & 1913 & 21 & 33 \\
\hline Malevich & 1915 & 26 & 37 \\
\hline Mondrian & 1912 & 19 & 40 \\
\hline Klee & 1922 & 15 & 43 \\
\hline Kandinsky & 1913 & 29 & 47 \\
\hline
\end{tabular}


Table 6: $\quad$ Number of Illustrations in Each Artist's Best Single Year as Share of Artist's Total Illustrations

\begin{tabular}{|l|c|}
\hline Artist & $\%$ \\
\hline \hline Boccioni & 55 \\
\hline de Chirico & 52 \\
\hline Munch & 34 \\
\hline Kirchner & 30 \\
\hline Malevich & 29 \\
\hline Kandinsky & 25 \\
\hline Klee & 17 \\
\hline Mondrian & 13 \\
\hline
\end{tabular}


Table 7: $\quad$ Share of Top 10\% of Paintings in Each Artist's Total Illustrations

\begin{tabular}{|l|c|c|}
\hline Artist & Share of top 10\% & $\begin{array}{c}\text { Total paintings } \\
\text { illustrated }\end{array}$ \\
\hline \hline Munch & 52 & 27 \\
\hline Boccioni & 48 & 15 \\
\hline Kirchner & 38 & 39 \\
\hline de Chirico & 37 & 26 \\
\hline Malevich & 37 & 55 \\
\hline Mondrian & 32 & 84 \\
\hline Klee & 28 & 67 \\
\hline Kandinsky & 25 & 82 \\
\hline
\end{tabular}


Table 8: $\quad$ Time Elapsed Between Earliest and Latest Years in Which Each Artist's Work Was Illustrated at Least Five Times

\begin{tabular}{|l|c|c|c|}
\hline Artist & Years elapsed & $\begin{array}{c}\text { Age in } \\
\text { earliest year }\end{array}$ & $\begin{array}{c}\text { Age in latest } \\
\text { year }\end{array}$ \\
\hline \hline Mondrian & 35 & 36 & 71 \\
\hline Kirchner & 18 & 28 & 46 \\
\hline Klee & 18 & 43 & 61 \\
\hline Kandinsky & 17 & 42 & 59 \\
\hline Munch & 7 & 30 & 37 \\
\hline Malevich & 6 & 34 & 40 \\
\hline de Chirico & 4 & 25 & 29 \\
\hline Boccioni & 3 & 28 & 31 \\
\hline
\end{tabular}

